\title{
10 \\ DA'WA, SOCIAL MEDIA AND CHALLENGE THE MAINSTREAM OF ISLAM AMONG MILLENNIAL GENERATION
}

\author{
Erwin Jusuf Thaib \\ IAIN Sultan Amai Gorontalo \\ erwinjthaib@iaingorontalo.ac.id
}

\begin{abstract}
This study aims to discuss the da'wa of Islam in relation to social media and how to challenge the mainstream of Islam among millennial generations in the community of Gorontalo City. The problem of this research is how the use of social media as a vehicle for da'wa for the millennial generation in Gorontalo City and what the challenges of da'wa for the millennial generation in Gorontalo City. This research uses qualitative methods, where data is obtained through observation, interviews and documentation studies. The findings of this study that social media can be used as a medium of da'wa especially for millennial generations. His da'wa material is the same as da'wa material in general, but the packaging follows the tastes of the millennial generation. Da'wa material on social media can be in the form of short narratives, pictures, or videos. Da'wa messages are delivered casually without patronizing. Nevertheless, there are challenges of da'wa on social media for the millennial generation in the form of the spread of hoaxes behind religious messages and the lack of adequate capacity of the millennial generation to filter religious messages so that they absorb whatever they find on social media. In conclusion, social media can be an alternative medium of da'wa in the delivery of da'wa for the millennial generation. However, there must be literacy efforts in accepting and understanding religious messages in social media so that they are not trapped in the massive hoax trap of today.
\end{abstract}

Keywords: Da’wa, social media, millennial, generation.

\begin{abstract}
Abstrak: Penelitian ini bertujuan untuk membahas dakwah Islam dalam kaitannya dengan media sosial dan bagaimana menantang arus utama Islam di kalangan generasi milenial di komunitas Kota Gorontalo. Permasalahan dalam penelitian ini adalah bagaimana penggunaan media sosial sebagai wahana dakwah bagi generasi milenial di Kota Gorontalo dan apa tantangan dakwah bagi generasi milenial di Kota Gorontalo. Penelitian ini menggunakan metode kualitatif, dimana data diperoleh melalui observasi, wawancara dan studi dokumentasi. Temuan penelitian ini bahwa media sosial dapat digunakan sebagai media dakwah terutama untuk generasi milenial. Bahan dakwahnya sama dengan bahan dakwah pada umumnya, tetapi kemasannya mengikuti selera generasi milenial. Materi dakwah di media sosial bisa dalam bentuk narasi pendek, gambar, atau video. Pesan dakwah disampaikan dengan santai tanpa menggurui. Namun demikian ada tantangan dakwah di media sosial untuk generasi milenial dalam bentuk penyebaran tipuan di balik pesan agama dan kurangnya kapasitas yang memadai dari generasi milenial untuk menyaring pesan agama sehingga mereka menyerap apa pun yang mereka temukan di media sosial. Kesimpulannya, media sosial bisa menjadi media alternatif dakwah dalam penyampaian dakwah untuk generasi milenial. Namun, harus ada upaya literasi
\end{abstract}


dalam menerima dan memahami pesan-pesan keagamaan di media sosial sehingga mereka tidak terjebak dalam perangkap tipuan besar-besaran saat ini.

Kata Kunci: Dakwah, media sosial, generasi milenial.

\section{A. Introduction}

Efforts to spread religion are basically a part that must exist in the lives of religious people. In Islam, this is called da'wa. Da'wa is the spread of Islam using principles rahmatan lil'alamin by upholding the value of morality, not through violence, coercion or force of arms. Therefore, every Muslim person has the responsibility as a preacher. The da'wa process is carried out on an on going basis which is handled by the preachers to change the object of preaching to be willing to enter the path of Allah SWT 247.

The above description shows how close the relationship between Islam and the da'wa movement. It can even be said that preaching in Islam is the existence of the religion of Islam itself, so tracing the history of da'wa in Islam is a search for the existence of Islam itself because the concept of Islam is a religion of da'wa both theory and practice. And the Prophet Muhammad as a religious leader in Islam was a preacher and in his mission of da'wa had succeeded in attracting people who originally disbelieved to be devout Muslims ${ }^{248}$.

Da'wa activities in the development and spread of Islam cannot be denied. The spread of Islam from Arabic to all corners of the world is inseparable from da'wa activities. In fact, in the dynamics of life that are organized until the creation of a better life is also influenced by the activities of da'wa. It shows how important the da'wa activities are in the development and progress of the Islamic religion ${ }^{249}$.

Basically da'wa aims to change the target of da'wa. Change is directed at aspects of perception, attitude and behavior. This activity is carried out by designing messages according to target trends and target religious diversity. This preparation needs to be done by paying attention to the characteristics of the target of da'wa as the recipient of the message ${ }^{250}$.

The logical consequence of the ideas above is the spread of da'wa messages through various channels that might be used as da'wa media. Traditionally, da'wa messages are delivered in a manner bil-lisan, meaning da'wa messages delivered in verbal languages such as lecturers, sermons, recitals and so forth. In addition, propaganda messages can also flow through the channel bil-hal, namely the delivery of da'wa through non-verbal languages such as behavior, attitudes, noble morality, even through marriage channels, trade, and so forth, as exemplified by the Prophet.

In the context of modernity, da'wa media is increasingly diverse as technology advances, especially information technology. Even though traditional propaganda channels are still in use, however, the presence of new media in society increasingly provides the possibility of spreading messages of da'wa more quickly and massively. These new media are electronic media such as telephone, radio, television and even the internet 251.

Da'wa today is demanded to be able to adjust to the dynamics of modern society. Associated with da'wa media, then utilizing advances in information technology is a must that cannot be negotiable. The presence of the internet in modern human life also presents a new model of social interaction among modern society. This interaction model uses social media that is present along

\footnotetext{
${ }^{247}$ Abdul Choliq. "Dakwah Melalui Media Sosial Facebook." Jurnal Dakwah Tabligh 16.2 (2015): 170

${ }^{248}$ Thomas Walker Arnold, Sejarah Da'wa Islam diterjemahkan oleh H. Nawawi Rambe dari judul aslinya The Preaching of Islam (Jakarta: Widjaya, 1981), 4-5.

${ }^{249}$ Wahyu Khoiruzzaman."Urgensi Dakwah Media Cyber Berbasis Peace Journalism." Jurnal Ilmu Dakwah 6.2 (2016): 320.

${ }^{250}$ Musthofa. "Prinsip Dakwah Via Media Sosial." Aplikasia: Jurnal Aplikasi Ilmu-ilmu Agama 16. 1 (2016): 53

${ }^{251}$ Everett M. Rogers, Communication Technology, The New Media in Society (New York: The Free Press; n.d.), 2.
} 
with the spread of the internet in the life of today's society. Today's society is fond of social media such as getting to know even having an account on Facebook, Twitter, Yahoo, Instagram, Youtube, Flickr and various other social media platforms ${ }^{252}$. The existence of social media has become a new identity in the current era. With these conditions, the da'wa interpreters must be able to utilize various social media platforms that exist as a vehicle for da'wa. Da'wa today requires a more interactive approach with the support of increasingly advanced information technology 253 .

Da'wa through social media is a picture of the compatibility of Islam with the dynamics of the times. Through social media, da'wa can reach all walks of life in a short time. The use of social media as a medium for da'wa will make room for the da'wa itself to achieve its effectiveness, especially in reaching missionary objects in the millennial era which are generally preoccupied with various activities that take up time and do not give too much opportunity to attend studies of Islamic da'wa conventional models that have been prevailing. Social media gave birth to a da'wa model that was in line with the character of millennial life.

Nevertheless, the da'wa that is transmitted through the mediation of social media also presents its own challenges for Islam as a whole. Social media platform that is of a nature open access making anyone able to play a role in filling the da'wa spaces available on social media. Without strict censorship both concerning the perpetrators of propaganda and propaganda content disseminated on social media, then the spread of da'wa on social media contains vulnerability among Muslims primarily related to perceptions, understandings, attitudes, and actions that are based on a variety of things that are absorbed from the da'wa that is transmitted through social media. Based on the description above, this article discusses the da'wa on social media, as well as the challenges faced in particular relating to the mainstream of Islam among millennials.

\section{B. Da'wa and Social Media}

The spread of Islam is inseparable from the role of a religious leader in da'wa. Da'wa is an activity to invite, encourage, and motivate others to walk the path of Allah and to fight together to elevate the religion of Allah. Therefore, terminologically the meaning of da'wa is interpreted as an invitation to the goodness and safety of the afterlife.

The main purpose of da'wa is to spread messages of virtue with various media including the latest communication media. If the Islamic religion does not use the latest multimedia technology, then the Islamic da'wa will be left behind and this will certainly cause harm to the development of Islamic da'wa. Just how is appropriate and good use of the latest media for the benefit of da'wa with positive values ${ }^{254}$.

Da'wa is an activity carried out continuously on the da'wa object. From time to time da'wa activities always experience changes in accordance with the conditions and situation. Da'wa is the duty of every Muslim in the simplest sense (on a micro scale) according to his capacity and ability. But in the sense of da'wa in an ideal and macro, both carried out by individuals and groups (organizations) must be done by mastering various aspects, both methods, materials, media, and mastering the da'wa targets ${ }^{255}$.

Da'wa is a series of activities or processes in achieving certain goals. In order for the message of preaching to the propaganda partners, the preachers must use various kinds of media da'wa methods (washilah) which can be used, both visual and audiovisual media. As for what is meant by da'wa media is a tool used in conveying da'wa material (Islamic teachings) to the object of da'wa. In this case da'wa can use various means. In the current era of globalization, da'wa must

\footnotetext{
${ }^{252}$ Nurudin."Media Sosial Baru dan Munculnya Revolusi Proses Komunikasi." Jurnal Komunikator 5.2 (2013): 84

${ }^{253}$ Faradillah Iqmar Omar."Penerimaan Media Sosial Sebagai Medium Dakwah Dalam Kalangan Mahasiswa KUIS (Kolej Universiti Islam Antarbangsa Selagor Malaysia)." E-proceedings of the Conference on Management and Muamalah (CoMM 2014) (2014): 67.

${ }^{254}$ Syafriwaldi." Dakwah dan Masalah Kontemporer." Jurnal Al-Fuad 1.1 (2017): 51

255Wahidin Saputra, Pengantar Ilmu Dakwah, (Jakarta: PT. Raja Grafindo Persada, 2012) h.2
} 
use the mass media of modern media such as newspapers, radio, television, film, internet, etc. ${ }^{256}$. The dimension of da'wa in internet-based media is a sign of a widespread cultural process, which involves an open space for da'wa participation. Previously the public (as an object of da'wa) was placed as an object in the process of da'wa, then became an active subject involved in the process of producing religious knowledge 257

Sociologically, the application of communication and information technology in life has changed the variety of people's interactions. The da'wa community is now not only those who are in plain sight, but also those who are together in an abstract space called the virtual world. The media has led individuals into spaces that allow each other to interact. The internet, for example, has now formed a virtual space where interactive greetings are then known as cyberspace ${ }^{258}$. Cyberspace is a biological child. Technology plays a major role in narrowing time, space and distance so that they are interconnected with each other in a space called cyberspace. In this space, all people across continents and across countries can then discuss and interact with one another 259 .

Da'wa through the internet is the latest innovation in Islamic symbols, and of course it will facilitate the da'i in spreading their da'wa wings. The use of internet media as da'wa media is an opportunity and challenge to develop and broaden the horizon of Islamic da'wa. The opportunity in question is how people who care about the ability of da'wa and utilize the internet media as a means and da'wa media to support the Islamic da'wa process. While making it happen starting from the energy, mind and human resources who understand the da'wa and the internet. Muslims must be able to master and make the most of the development of information technology, "In terms of da'wa, the power of the internet is very potential to be utilized ${ }^{260}$.

Besides being useful for da'wa, the internet also provides information and data, all of which make it easier for people to work. Therefore, it is an irony if among the ulama there is still a fatwa forbidding the internet for educational institutions or propaganda institutions because this media is seen as containing information that is full of lies and pornographic images that damage morals. If Muslims do not immediately take advantage of the media in the current global era, the Islamic da'wa will be alienated and marginalized in the midst of competition from secular ideologies and other major religions. ${ }^{261}$

As said by Sheikh Sulthan al-Umari in his paper Istikhdam al-Internet fi ad-Da'wa, that there are some important things to consider when preaching in cyberspace:262

First, the most basic thing is to correct intention. Da'wa on the internet will be smooth if it is based on good intentions, otherwise it is not intended to dredge the material or dissolve in a school of thought debate, for example.

Second, formulating the vision and mission of da'wa in cyberspace. In this context it is important to understand that the essence of da'wa is to benefit others. Da'wa is leading to the good and positive realm. A narrated history from Abu Hurairah says that whoever invites the guidance of goodness receives the same reward from the person concerned.

Third, show the world the majesty of the noble values of Islam.

\footnotetext{
${ }^{256}$ Effendi Sadly. "Manajemen Dakwah Media Sosial: Telaah Terhadap Perkembangan Metode Dakwah Islam." Jurnal Riset Manajemen dan Bisnis (JRMB) 3.2 (2018): 45

${ }^{257}$ Efa Rubawati."Media Baru: Tantangan dan Peluang Dakwah." Jurnal Studi Komunikasi 2 (2018): 128

${ }^{258}$ Asep Saeful Muhtadi, "Komunikasi Dakwah: Teori, Pendekatan, Dan Aplikasi" (Bandung: Simbiosa Rekatama Media, 2012), hal.60.

${ }^{259}$ Wasisto Raharjo Jati. "Cyberspace, Internet, dan Ruang Publik Baru: Aktivisme Online Politik Kelas Menengah Indonesia." Jurnal Pemikiran Sosiologi 3.1 (2016): 26

${ }^{260}$ Nur Ahmad."Tantangan Dakwah di Era Teknologi dan Informasi: Formulasi Karakteristik, Popularitas, dan Materi di Jalan Dakwah." Jurnal ADDIN 8 (2014): 326-327

${ }^{261}$ Ahmad Zaini. "Dakwah Melalui Internet." At-Tabsyir, Jurnal Komunikasi Penyiaran Islam 1.1 (2013): 103104.

${ }^{262}$ Ahmad Zaini.” Dakwah Melalui Internet. “, 94.
} 
Fourth, choose a supervisor or controller of quality content that is competent in sharia matters and has broad insight. This will help avoid content controversies and contradictions.

Fifth, content is always adjusted to the needs of the present and current trends of society.

And finally, if you make a specific da'wa site, then don't forget to complete it with superior applications, such as forums, live chatting (chat), and electronic mail facilities (e-mail).

\section{Millennial Generations and Social Media}

One of the popular terms today is the term millennial. This term is usually associated with a particular generation called millennial generation who lived in a certain era called the millennial era. The term millennial comes from the English word millennium or millennia which means a thousand years 263 .

Millennial is a cohort term in demographics, a noun meaning followers or groups. There are currently four major cohorts in demographics, namely Baby Boomers (born in 19461964), GenX (born in 1965-1980), Millennial (born in 1981-2000), and Gen-Z (born in 2001 -now). In other literature, according to Absher and Amidjaya that the millennial generation is the generation born between 1982 and 2002, the difference is not too significant. The current millennial generation (in 2017) are those aged 17-36 years; those who now play the role of students, early jobs, and young parents 264 .

Millennial generation is the generation that lives with certain characteristics. According to Andi Hidayat ${ }^{265}$ millennial generation characteristics are:

First, millennials trust User Generated Content more than unidirectional information.

Millennials don't believe in one-way information. They don't really trust big companies and advertisements; they are more concerned with personal experience than conventional advertisements or reviews. For example, in terms of buying a product, this generation looks at product reviews and testimonials before buying it.

Second, millennials prefer cellphones over TVs

The internet plays a very important role in life in this generation. For millennials, advertising on television is usually avoided. The millennials prefer to get information from their cellphones, by searching Google or talking in forums, which this generation follows to keep up-to-date on the surroundings.

Third, millennials must have social media.

Communication that runs on millennials is very smooth. However, that does not mean that communication always happens face to face, but quite the opposite. Many millennials do all their communication through text messaging or also chatting in cyberspace, by creating accounts that contain their profiles, such as Twitter, Facebook, to Line. Social media accounts can also be a place for self-actualization and expression, because what is written about him there is what everyone will read. So, almost all millennials are certain to have social media accounts as a place for communication and expression.

Fourth, millennials do not like to read conventionally.

The population of people who like to read books dropped dramatically in the millennial generation. For this generation, writing is considered frustrating and boring. Millennials are arguably more like seeing pictures.

Fifth, millennials know more about technology than their parents.

This generation sees the world not directly, but in a different way, by surfing in cyberspace, so that they come to know everything. Starting from communicating, shopping, getting information and other activities.

Sixth, millennials tend to be disloyal but work effectively.

${ }^{263}$ John M. Echols dan Hasan Shadily, Kamus Inggris Indonesia (Jakarta: PT Gramedia Pustaka Utama, 1980), h. 380 .

264Iffah al-Wahidah."Tabayyun di Era Generasi Millenial."Jurnal Living Hadis 2.1 (2017): 320-321

${ }^{265}$ Andi Hidayat."Metode Pendidikan Islam Untuk Generasi Millenial." Fenomena: Jurnal Penelitian 10.1

(2018): 68 
In connection with the characteristics of millennial generation which is heavily influenced by information technology, the internet and social media, the main issues that are the focus of millennial generation's attention cannot be separated from their close relations with information technology, the internet and social media. The main issues include:

\section{Views on religion.}

This view is very important for the millennial generation because after all Indonesia in particular is a country that prioritizes the religion of Islam, even though the basic state uses Pancasila and UUD 1945, but still the basis of religion and philosophy of life must be based on religion, because in this generation so fast globalization and technological currents that sometimes religious norms are often forgotten even they are more concerned with gadgets than religious teachings.

\section{Social Values}

How a human being must interpret the meaning of a family and the environment, because the relationship between humans, both family, friends will be a good place of protection, various problems that will arise for this generation, namely the lack of socialization, they prefer to interact by using their gadget so that there will be a shift social values.

\section{Education}

The most important issue among this generation is education, this issue will direct how it will lead to the future, but the problems that arise are very risky for this generation, they tend to be lazy because of the information they get so easily using gadgets, they only placing schools only as the fulfillment of obligations legalized with a diploma, so that for many of them education is no longer a priority266.

Of the three main issues that are the main focus of millennial generation as expressed above, it can be seen that the dominance of information technology, the internet, and social media plays a role in changing or shaping millennial generation perceptions of aspects of social life that prevailed in previous generations. Millennial generation tends to the practical aspects related to religious values, education, and social values.

The tendency of millennial generation in gaining knowledge and understanding instantly, can be understood positively and negatively. Positively, the acquisition of information, knowledge and understanding that will quickly enrich the knowledge and information that can be reached easily. Nevertheless, the practicality and ease of gaining knowledge and understanding, primarily religious knowledge and understanding, will make the millennial generation lazy in accessing the main sources of knowledge and knowledge and understanding obtained from the internet tend to be partial and not well filtered. Therefore, the generation born with these characteristics is a generation that is rich in information and knowledge but not profound. In a religious context, the characteristics of knowledge and understanding like this tend to be dangerous because it will give birth to a millennial generation of Islam that does not have a deep religious knowledge base, a capital that is needed in navigating life in the millennial era that increasingly threatens the existence of religion itself.

\section{Da'wa, Social Media ant It's Challenge in Millennial Era.}

Gorontalo society is a society that is identical with Islam. View of life and customs based on Islam have been integrated with people's lives. The religiosity of the people of Gorontalo can be seen from the philosophy of life: "Adati hula hula'a to sara'a, sara'a hula hula'a to Kuru'ani." This philosophy can be interpreted as customs based on syara 'and syara' based on the Qur'an. This philosophy later became the frame of the Gorontalo community's Islamic tradition ${ }^{267}$. In this condition of society, Islamic da'wa is growing, including da'wa in digital media.

${ }^{266}$ Andi Hidayat."Metode Pendidikan Islam Untuk Generasi Milenial.", 69

${ }^{267}$ Erwin Jusuf Thaib." DiiKili Sebagai Ekspresi Islam Nusantara dalam Budaya Islam Lokal Gorontalo: Perspektif Dakwah Islamiyah." Jurnal Al-Ulum 16.1 (2016): 107-108 
The digital age brings significant changes in social life. The era marked by advances in information technology gave birth to a community called digital society that responded to social dynamics and change very quickly. Digital society has unique life characteristics especially when related to its relationship with communication technology and the internet. And the main element of digital society is millennial generation. In a digital society, access to information is very broad and moves so fast. Support of communication devices and internet connections make anyone can access any information. This phenomenon can easily be found in Gorontalo City society.

One aspect of social life that gets a touch of openness in the digital age is the religious aspect. Gorontalo City people easily obtain religious information and disseminate it through the mediation of social media platforms that are so popular in the community. Looking for religious information and also disseminating it is one of the special characteristics of Islamic da'wa in the digital age.

Da'wa in the millennial era must utilize the media, especially new media. The development of communication technology has changed the way people communicate. Today, almost everyone uses the internet to send, search and read information. Even in interacting mostly through social media rather than direct communication. This is possible to happen, at least, influenced by several factors, including the rapid development of information and communication technology, the tendency of millennial society that depends on the media. In relation to da'wa, the role of the media is very strategic in the delivery of da'wa messages. The media is able to penetrate the boundaries of space and time. That is, even with long distance communication is possible. Not only that, the media also offers speed in providing a variety of information ${ }^{268}$.

This phenomenon is a challenge as well as the da'wa opportunities that must be faced. For that, there are two things that can be done. First, related to the use of da'wa media. In the current digital era, gadgets and social media cannot be separated from millennial generation. So, gadgets and social media must be used as a da'wa. Da'wa messages must be packaged through content that is familiar with the current generation. The use of da'wa portal with content is not always in the form of writing, but can also be packaged in the form of vlogs, sound cloud, infographics, and also memes, loaded on YouTube so that da'wa is more widespread. Da'wa can also be done online by utilizing YouTube, Instagram, and so on. Second, the packaging of da'wa messages must be interesting. Because, no matter how good the da'wa material without being supported with attractive packaging is sometimes left by people. With these two approaches, the challenges of da'wa in the millennial generation can be passed and resolved well269.

In the context of Gorontalo City society, the challenges of da'wa through social media in the form of millennial generation:

First, challenges from the da'wa side are related to the ability to use da'wa media and the ability to package da'wa messages in accordance with millennial tastes.

In the millennial era there was a shift in the da'wa paradigm from the traditional conservative model to the contemporary da'wa era. This open means that the old da'wa model has been abandoned altogether, but responding to the development of the era then the da'wa adapted itself to the dynamics of the era marked by the use of information technology advancements as open missionary space open continuously.

The negative stigma about the internet and everything related to it is still embedded in some preachers in Gorontalo City. As a result they avoid it and do not take the opportunity to use it for the development of da'wa. In addition, technically many preachers are still technologically illiterate. So that even if they adopt social media as a da'wa media, the da'wa package is still conservative in the sense of only moving the da'wa activity from the real world to the virtual world. So, from the content and also the da'wa package is not able to attract the interest of millennial generation.

268Muhammad Habibi."Optimalisasi Dakwah Melalui Media Sosial di Era Milenial." Al-Hikmah: Jurnal Dakwah 12.1 (2018): 101-102

${ }^{269}$ Muhammad Habibi."Optimalisasi Dakwah Melalui Media Sosial di Era Milenial.", 108-109 
Second, the tendency of millennial generation to absorb religious information not from its main source but from the internet.

The internet era has played a role in changing the trend of searching for religious information in millennial generations from conventional sources such as religious books, kitab kuning, tafsir, hadis, and other primary religious sources and turning to internet sources. This phenomenon can also be found among millennials in Gorontalo City. The nature of the internet is practical and fast, providing a variety of information, more interesting than learning by the old method.

Third, hoaxes that hide behind da'wa messages.

Hoax is information or news that contains things that are uncertain or that really are not facts that occur. The phenomenon of hoaxes on social media is something that is often found even in relation to religious messages such as propaganda can also be seen in Gorontalo City society, especially users of social media.

The presence of hoaxes in da'wa messages on social media is a serious problem because it is contrary to the purpose of preaching itself. It may be that people will tend to avoid da'wa messages on social media even though they are not exposed to hoax elements.

The three challenges of da'wa above are issues that must get serious attention so that the movement of preaching on social media to millennials in Gorontalo City can get positive results in the context of developing da'wa by utilizing da'wa media that is relevant to the dynamics of the times, especially social media as one of the media main communication in the millennial era. The use of modern communication media in spreading da'wa messages will give an idea of the suitability of Islam with the dynamics of the times.

Da'wa preachers in Gorontalo City must take the opportunity to utilize social media in order to reach the missionary objects of millennial. Technical and psychological barriers in the use of social media as a medium for da'wa can be overcome by social media literacy movements, both about the technical aspects, packaging of da'wa content, and efforts to overcome the inclusion of hoax content in da'wa messages on social media.

\section{E. Conclusion}

Islamic da'wa in its development in Gorontalo City must always adopt various communication media that develop in the millennial era, especially social media. The use of social media as a medium for da'wa can reach a millennial generation who is always connected to social media anytime, anywhere. Thus, da'wa can continue without hindrance by the limitations of space and time.

The use of social media as a medium for da'wa will always be confronted with challenges, both from the aspect of missionary da'wa, da'wa material, and the spread of hoaxes in da'wa messages. But this can be overcome by continuing to provide education and literacy in the use of healthy social media in order to avoid the hoax that is aggressively disseminated in da'wa messages on social media.

\section{References}

Ahmad, Nur."Tantangan Dakwah di Era Teknologi dan Informasi: Formulasi Karakteristik, Popularitas, dan Materi di Jalan Dakwah." Jurnal ADDIN 8 (2014)

Arnold, Thomas Walker, Sejarah Da'wa Islam diterjemahkan oleh H. Nawawi Rambe dari judul aslinya The Preaching of Islam (Jakarta: Widjaya, 1981)

Choliq, Abdul."Dakwah Melalui Media Sosial Facebook." Jurnal Dakwah Tabligh 16.2 (2015)

Echols, John M., dan Shadily, Hasan, Kamus Inggris Indonesia (Jakarta: PT Gramedia Pustaka Utama, 1980) 
Habibi, Muhammad."Optimalisasi Dakwah Melalui Media Sosial di Era Milenial." Al-Hikmah: Jurnal Dakwah 12.1 (2018)

Hidayat, Andi."Metode Pendidikan Islam Untuk Generasi Millenial." Fenomena: Jurnal Penelitian 10.1 (2018)

Jati, Wasisto Raharjo."Cyberspace, Internet, dan Ruang Publik Baru: Aktivisme Online Politik Kelas Menengah Indonesia." Jurnal Pemikiran Sosiologi 3.1 (2016)Juditha, Cristiany."Interaksi Komunikasi Hoax di Media Sosial Serta Antisipasinya." Jurnal Pekommas 3.1 (2018)

Khoiruzzaman, Wahyu."Urgensi Dakwah Media Cyber Berbasis Peace Journalism." Jurnal Ilmu Dakwah 6.2 (2016)

Muhtadi, Asep Saeful, "Komunikasi Dakwah: Teori, Pendekatan, Dan Aplikasi” (Bandung: Simbiosa Rekatama Media, 2012)

Musthofa."Prinsip Dakwah Via Media Sosial." Aplikasia: Jurnal Aplikasi Ilmu-ilmu Agama 16.1 (2016)

Nurudin." Media Sosial Baru dan Munculnya Revolusi Proses Komunikasi." Jurnal Komunikator 5.2 (2013)

Omar, Faradillah Iqmar."Penerimaan Media Sosial Sebagai Medium Dakwah Dalam Kalangan Mahasiswa KUIS (Kolej Universiti Islam Antarbangsa Selagor Malaysia) E-proceedings of the Conference on Management and Muamalah (2014)

Rogers, Everett M., Communication Technology, The New Media in Society (New York: The Free Press; n.d.)

Rubawati, Efa."Media Baru: Tantangan dan Peluang Dakwah." Jurnal Studi Komunikasi 2 (2018)

Sadly, Effendi."Manajemen Dakwah Media Sosial: Telaah Terhadap Perkembangan Metode Dakwah Islam." Jurnal Riset Manajemen dan Bisnis (JRMB) 3.2 (2018)

Saputra, Wahidin, Pengantar Ilmu Dakwah, (Jakarta: PT. Raja Grafindo Persada, 2012)

Syafriwaldi." Dakwah dan Masalah Kontemporer." Jurnal Al-Fuad 1.1 (2017)

Thaib, Erwin Jusuf." DiiKili Sebagai Ekspresi Islam Nusantara dalam Budaya Islam Lokal Gorontalo: Perspektif Dakwah Islamiyah." Jurnal Al-Ulum 16.1 (2016)

al-Wahidah, Iffah."Tabayyun di Era Generasi Millenial." Jurnal Living Hadis 2.1 (2017)

Zaini, Ahmad."Dakwah Melalui Internet At-Tabsyir, Jurnal Komunikasi Penyiaran Islam 1.1 (2013) 